\title{
Synthesis and structure confirmation of 2,4-disubstituted thiazole and 2,3,4-trisubstituted thiazole as thiazolium bromide salts
}

\author{
Alaa A. Hassan ${ }^{1}$ (D) $\cdot$ Nasr K. Mohamed ${ }^{1} \cdot$ Ashraf A. Aly $^{1} \cdot$ Hendawy N. Tawfeek $^{1} \cdot$ Stefan Bräse $^{2,3} \cdot$ Martin Nieger $^{4}$
}

Received: 18 December 2019 / Accepted: 8 June 2020 / Published online: 18 June 2020

(c) The Author(s) 2020

\begin{abstract}
The synthesis of 4-substituted 2-(2-arylhydrazinyl)thiazol-3-ium bromides and 4-aryl-2-(substituted amino)-3-(phenylamino)thiazol-3-ium bromide derivatives in high yields from the interaction of mono- and di-substituted thiosemicarbazides with phenacyl bromide derivatives is reported. The synthesized products have been elucidated using various spectroscopic tools such as IR, NMR, and mass spectrometry. Also the structure of three of the obtained compounds have been confirmed using X-ray crystallographic analyses, which showed that compounds 2-[2-(2,4-dinitrophenyl)hydrazinyl]-4-phenylthiazol-3-ium bromide and 4-phenyl-2,3-bis(phenylamino)thiazol-3-ium bromide crystals have a monoclinic shape and belonged to space group $P 2{ }_{1} / c$, whereas the crystals of 4-phenyl-2-(2-tosylhydrazinyl)thiazol-3-ium bromide show an orthorhombic shape with the space group $P b c a$
\end{abstract}

\section{Graphic abstract}

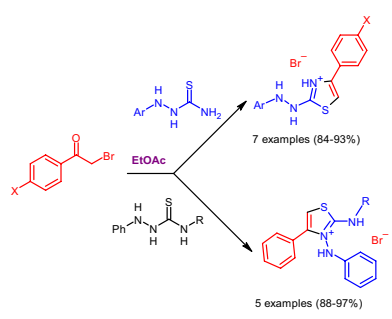

Keywords Carbonyl compounds · Crystal structure · Cyclizations · Eliminations · Thiazolium bromide derivatives · Thiosemicarbazides

Electronic supplementary material The online version of this article (https://doi.org/10.1007/s00706-020-02640-3) contains supplementary material, which is available to authorized users.

Alaa A. Hassan

alaahassan2001@mu.edu.eg

1 Chemistry Department, Faculty of Science, Minia University, El Minia 61519, Egypt

2 Institute of Organic Chemistry, Karlsruhe Institute of Technology, 76131 Karlsruhe, Germany

3 Institute of Biological and Chemical Systems (IBCS-FMS), Karlsruhe Institute of Technology, Eggenstein-Leopoldshafen, Germany

4 Department of Chemistry, University of Helsinki, A. I. Virtasen aukio I, P.O. Box 55, 00014 Helsinki, Finland

\section{Introduction}

Generally the thiazole core occurs in variety of pharmaceutical drugs [1]. For example, the water-soluble vitamin B1 thiamine possesses a thiazole ring within its structure [2]. In addition, the thiazole ring system appears in the bacitracin and penicillin antibiotics and plays a great role in the construction of synthetic drugs [1].

Synthetic drugs related to thiazole family recorded as antimicrobial agents acinitrazole and sulfathiazole [3], penicillin which used as antibiotic $[4,5]$, pexole antidepressant drugs [6], bleomycin antineoplastic agents and tiazofurin [7], ritonavir used as anti-HIV drug [8], cinalukast antiasthmatic drug [9], nizatidine antiulcer agent [10]. The non-steroidal immunomodulatory drug fanetizole was extensively 
used as thiazole derivatives [11] and meloxicam used as anti-inflammatory drug [12]. Thiazole derivatives possess polyoxygenated phenyl molecule that showed anti-fungal activity [13]. Thiazolium salts and bis-thiazolium salts have been prepared and examined as antimalarial potent agents [14]. Imidazo[2,1-b]thiazolium bromides showed analgesic and anti-inflammatory activities [15].

The synthetic strategies of thiazolium bromide heterocyclic cores were achieved via more than one step reaction, in which the thiazole ring was constructed first, then alkylation of the thiazole ring using alkyl bromide derivatives, for instance $N$-dodecylthiazolium bromide, and $N$-dodecyl4-methylthiazolium bromide, were observed during the reaction of 1-bromododecane and thiazole/4-methylthiazole, and have been investigated as antimicrobial agents [16]. A few reactions have been reported for the synthesis of thiazolium bromides in one step procedures, such as the reaction between thiosemicarbazide and 2-bromo-1-(4-chlorophenyl)ethanone affording 1-[5-(4-chlorophenyl)thiazol-2-yl]hydrazine hydrobromide and investigated as antibacterial [17]. Also, (E)-2-[2-(2-nitrobenzylidene)hydrazinyl]-4-phenylthi azol-3-ium bromide was synthesized from the reaction of 1-aryl-2-bromoethanones with 2-(1-substituted methylidene)hydrazinecarbothioamides [18].

Polymethylene-bridged thiazolium and benzothiazolium salts (plus bases) were used as catalysts for the benzoin condensation; bis(thiazolin-2-ylidene) not thiazolin-2-ylidenes, were found to be the catalytic species in the benzoin condensation catalyzed by thiazolium salts plus base [19]. Thiazolium bromide salts have been used as catalyst for the synthesis of 1,4-diketones via hydroacylation of chalcones $(\alpha, \beta$-unsaturated ketones) with aldehydes [20].

3-[2-(1-Butyl-1 $H$-imidazol-1,3-ium-3-yl)ethyl]-4,5-dimethyl-1,3-thiazol-3-ium was used as an ionic liquid in the conversion of aldehydes to acyloins and benzoins [21]. Thiazolium salts have been synthesized and their properties as ionic liquid catalyst have been studied; thiazolium halide ionic liquids were synthesized by using 4-methylthiazole or 4-methyl-5-thiazolethanol and alkyl halides [22].

Reactions between mono-substituted thiosemicarbazides with phenacyl bromide derivatives in ethanol at refluxing temperature have been reported and gave 2-amino-5-(4aminophenyl)-4-(phenyl)-1,3-thiazol-3-ium bromide dihydrate derivatives. Also the same reactions have been carried out using Eschenmoser coupling reaction conditions, triethyl amine (base) and triphenylphosphine (thiophile) in acetonitrile resulting in the formation of diazinylthiazole derivatives [23].

Lee et al. reported that the synthesis of 2-amino-5-( $p$ aminophenyl)thiazoles and 5,5'-bis (2-aminothiazole) derivatives via [5.5] sigmatropic shift of $N$-phenyl- $N^{\prime}$-(2-thiazolyl)hydrazones and $N, N^{\prime}$-bis(2-thiazolyl)hydrazines in acid catalyzed benzidine type rearrangement [24].

\section{Results and discussion}

\section{Reaction between 4-substituted thiosemicarbazides and phenacyl bromides}

Herein, we investigate the reactions between 4-substituted thiosemicarbazides 1a-1d with phenacyl bromide derivatives (as $\alpha$-halocarbonyl compounds) $\mathbf{2 a}$ and $\mathbf{2 b}$ in ethyl acetate at room temperature that resulted in the formation of 4-substituted-2-(2-substituted hydrazinyl)thiazol-3-ium bromide 3a-3g in high yields (84-93\%) as showed in Scheme 1. The structures of the synthesized compounds $\mathbf{3 a}-\mathbf{3 g}$ were identified using various tools of spectroscopic analyses, and also the structure of $\mathbf{3 a}$ and $\mathbf{3 d}$ were confirmed using X-ray analyses.

In the IR spectrum of compound 3a, broad bands were observed at $3220 \mathrm{~cm}^{-1}$ due to $\mathrm{NH}, 3102 \mathrm{~cm}^{-1}$ because of aromatic- $\mathrm{CH}$, at $1611 \mathrm{~cm}^{-1}$ due to $\mathrm{C}=\mathrm{N}$, at $1591 \mathrm{~cm}^{-1}$ attributed to aromatic $\mathrm{C}=\mathrm{C}$, and at 1535 and $1331 \mathrm{~cm}^{-1}$ due to $\mathrm{NO}_{2}$ group.

The ${ }^{1} \mathrm{H}$ NMR spectra of 3a showed broad signals at $\delta=10.20 \mathrm{ppm}$ due to $\mathrm{NH}$-attached directly to 2,4 -dinitrophenyl moiety, while $\mathrm{NH}$-attached to $\mathrm{C}-2$ appeared at $10.63 \mathrm{ppm}$. The two NH-protons show downfield shift, attributed to the high deshielding caused by the di-nitro groups on the aromatic ring and the positive charge on thiazole-ring, respectively, as observed from the X-ray structure analysis of 3a. The thiazole- $\mathrm{H}$ occurred at $7.82 \mathrm{ppm}$ as singlet signal. The aromatic protons appeared at 7.21-7.40 and 7.48-7.55 ppm due to the phenyl protons. The protons appeared at 8.34-8.43 and 8.83-8.92 ppm are of the 2,4-dinitrophenyl protons.

In ${ }^{13} \mathrm{C}$ NMR of 3a, signals at $115.6,150.5$, and $170.5 \mathrm{ppm}$ due to thiazole C-5, C-4, and C-2 respectively, also the downfield shift attributed to the positive charge on the thiazole ring. The aromatic carbons appeared at the aromatic region as mentioned in the experimental part.

The mass spectrum of 3a showed that $m / z=443\left(\mathbf{M}^{+}\right)$ confirmed the formation of the thiazolium bromide products via the condensation between thiosemicarbazide 1a and phenacyl bromide 2a. The base peak at $m / z=358$ resulted under liberation of $\mathrm{HBr}$ molecule.

\section{X-ray structure of compounds $3 a$ and $3 d$}

The structure of $\mathbf{3 a} \mathbf{a} \mathbf{3} \mathbf{g}$ was further confirmed by X-ray diffraction of 4-phenyl-2-[2-(2,4-dinitrophenyl)hydrazinyl]thiazol-3-ium bromide (3a; Fig. 1 and Tables 1-7 in the supplementary data: note that the crystal numbering does not obey the IUPAC numbering rules) and 4-phenyl-2-(2tosylhydrazinyl)thiazol-3-ium bromide (3d; Fig. 2 and 
Scheme 1

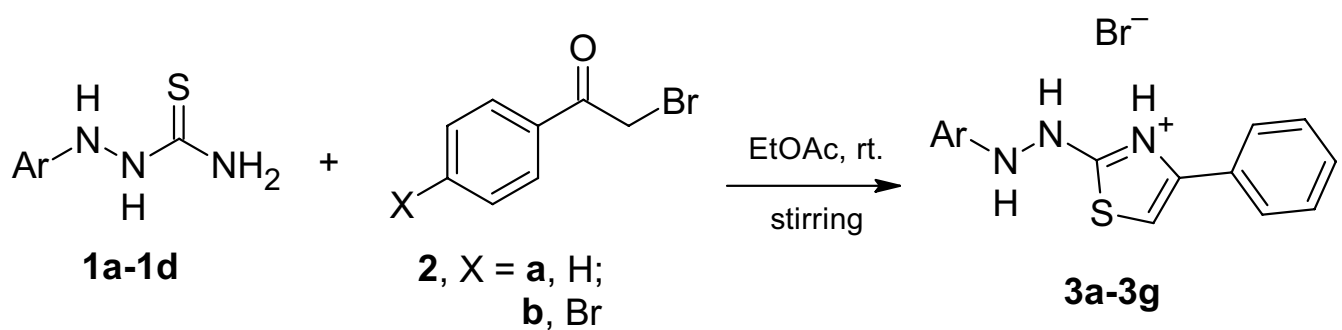

3a-3d: $X=H$

a, $\mathrm{Ar}=2,4$-dinitro- $\mathrm{C}_{6} \mathrm{H}_{3} ; \mathbf{b}, \mathrm{Ar}=\mathrm{C}_{6} \mathrm{H}_{5}$;

c, $\mathrm{Ar}=3-\mathrm{Cl}-\mathrm{C}_{6} \mathrm{H}_{4} ; \mathbf{d}, \mathrm{Ar}=4-\mathrm{Me}-\mathrm{C}_{6} \mathrm{H}_{4} \mathrm{SO}_{2}$.

3e-3g: $X=\mathrm{Br}$

$\mathbf{e}, \mathrm{Ar}=\mathrm{C}_{6} \mathrm{H}_{5} ; \mathbf{f}, \mathrm{Ar}=3-\mathrm{Cl}-\mathrm{C}_{6} \mathrm{H}_{4}$;

g, $\mathrm{Ar}=4-\mathrm{Me}-\mathrm{C}_{6} \mathrm{H}_{4} \mathrm{SO}_{2}$.

Tables $8-14$ in the supplementary data), both showed the planarity of the thiazole ring.

\section{Plausible mechanism for the formation of hydrazinylthiazolium bromide derivatives $3 \mathrm{a}-\mathbf{3 g}$}

The plausible mechanism for the formation of $\mathbf{3 a}-\mathbf{3 g}$ was demonstrated in Scheme 2 as follows: $S$-alkylation takes place via nucleophilic substitution and elimination of $\mathrm{HBr}$ molecule to give intermediate $\mathbf{4}$. Heterocyclization of $\mathbf{4}$ through nucleophilic attack of $\mathrm{N}^{4}$ on the carbonyl-group followed by elimination of $\mathrm{H}_{2} \mathrm{O}$ molecule gives 6 . In the presence of $\mathrm{HBr}$ the thiazolium bromide derivatives $\mathbf{3 a}-\mathbf{3} \mathbf{g}$ are formed.

\section{Reactions between 1,4-disubstituted thiosemicarbazides $7 a-7 e$ and phenacyl bromide $2 a$}

Also, in this paper we investigate the reactions between 1,4-disubstituted thiosemicarbazides $\mathbf{7 a - 7 e}$ and phenacyl bromide (2a) in ethyl acetate at room temperature resulting in the formation of 4-aryl-2-(amino)-3-(phenylamino) thiazol-3-ium bromide derivatives 8a-8e in high yields (88-97\%) instead of (Z)-3-substituted 4-diphenyl-2-(2phenylhydrazono)-2,3-dihydrothiazoles 9a-9e [23] (Scheme 3). Here, we try to carry out the reaction in a variety of solvents and conditions; we found that the products were formed in high yields and purity when the reactions were carried out in ethyl acetate at room temperature (Table 1).

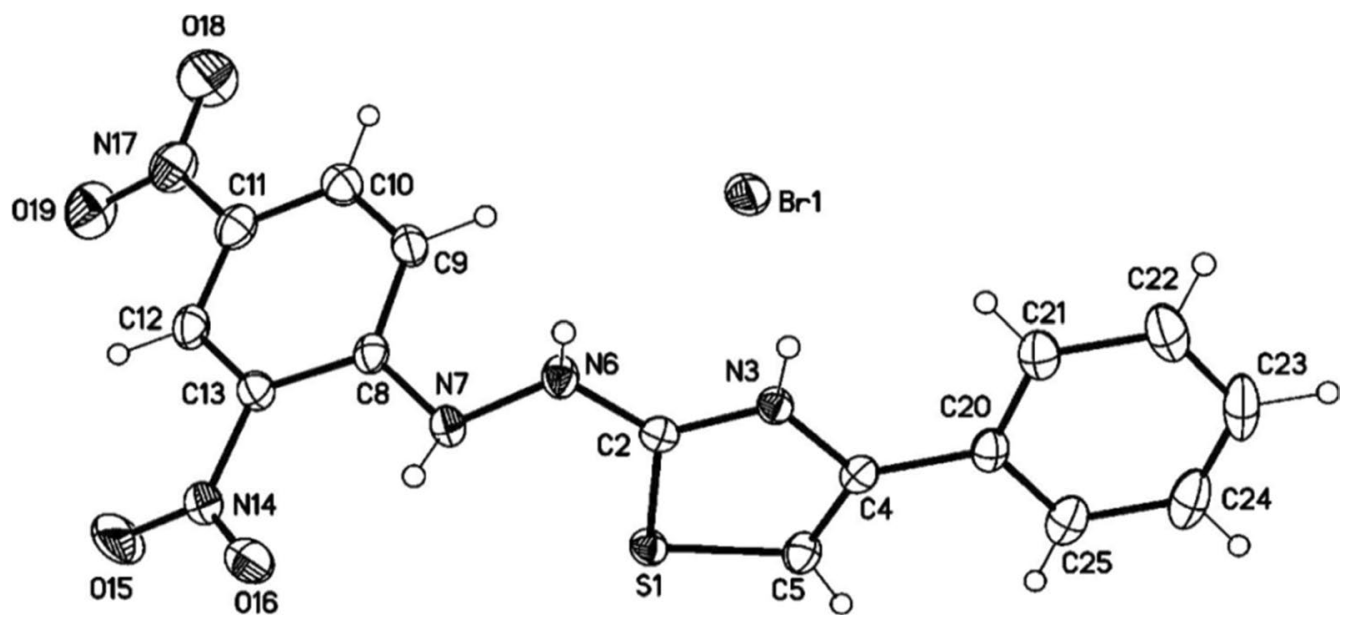

Fig. 1 Molecular X-ray structure of 2-[2-(2,4-dinitrophenyl)hydrazinyl]-4-phenylthiazol-3-ium bromide (3a) 


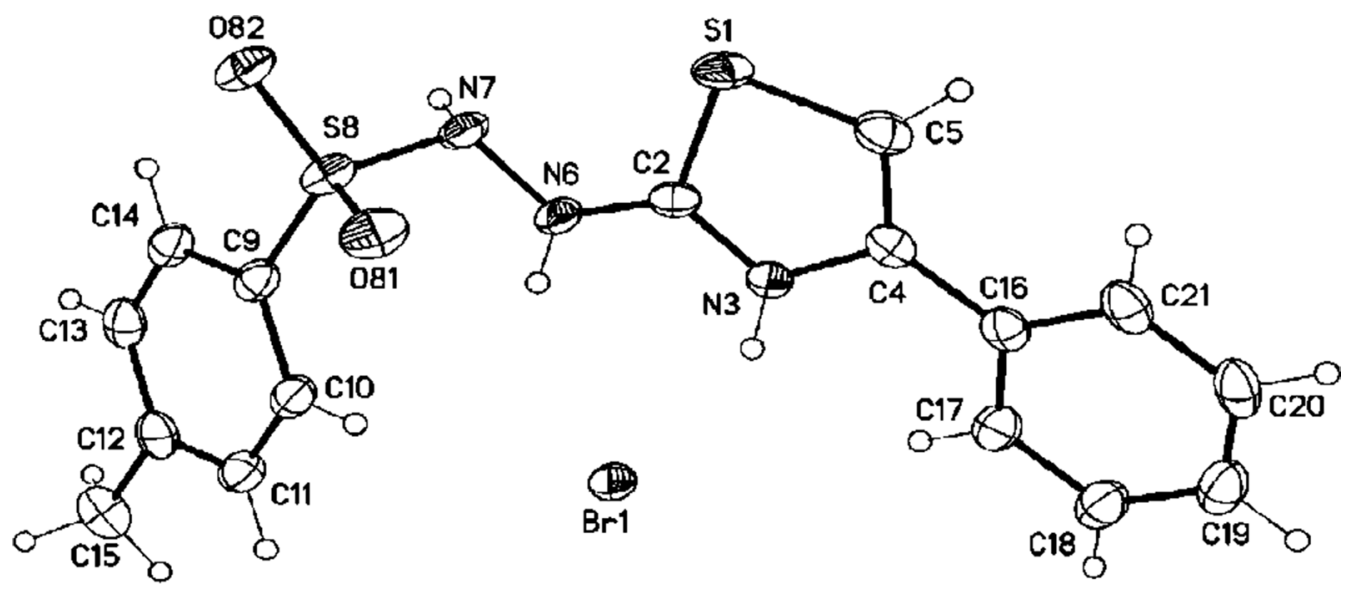

Fig. 2 Molecular X-ray structure of 4-phenyl-2-(2-tosylhydrazinyl)thiazol-3-ium bromide (3d)

Scheme 2<smiles>NC(=S)NNC=[18O]</smiles><smiles>[X]c1ccc(C(=O)CBr)cc1</smiles>

S-alkylation<smiles>CNN[Al]N</smiles>

$2 a, 2 b$<smiles>[X]c1ccc(-c2csc(NN[Al])n2)cc1</smiles>

\section{3a-3g}

The structures of compounds 8a-8e were confirmed using spectroscopic methods, such as IR, ${ }^{1} \mathrm{H}$ NMR, ${ }^{13} \mathrm{C}$ NMR, and mass spectrometry as well as $\mathrm{X}$-ray crystallographic analysis.
In IR spectrum of $\mathbf{8 a}$ there are characteristic absorption bands that appeared at $3220-3175 \mathrm{~cm}^{-1}$ assigned to $\mathrm{NH}-$ group vibrations, aromatic- $\mathrm{CH}$ vibrations observed in the 
region around 3025-3135 $\mathrm{cm}^{-1}$, and absorption band at $1595 \mathrm{~cm}^{-1}$ assigned to $\mathrm{Ar}-\mathrm{C}=\mathrm{C}$ vibrations. .

From the ${ }^{1} \mathrm{H}$ NMR spectra of $8 \mathbf{a}$ it was cleared that broad singlet signals appeared downfield at $\delta=9.88 \mathrm{ppm}$ due to deshielded NH-proton, the downfield shift caused by the occurrence of the positive charge on the thiazole-ring, and the other NH-proton appeared within the aromatic protons.

The ${ }^{13} \mathrm{C}$ NMR showed signals at $\delta=112.7,138.0$, and 168.6 ppm for thiazole C-5, C-4, and C-2, respectively. The aromatic carbons appeared at the characteristic region as illustrated in the experimental part.

The interaction between $7 \mathbf{a}-\mathbf{7 e}$ and $\mathbf{2 a}$ resulted in the formation of 4-aryl-2-(substituted amino)-3-(phenylamino)thiazol-3-ium bromide derivatives $\mathbf{8 a}-\mathbf{8 e}$ was supported from the mass spectrometry of compound $\mathbf{8 a}$ which showed $m / z=425\left(\mathrm{M}^{+}\right)$this peak is due to the presence of $\mathrm{HBr}$ molecule and formation of the thiazolium salt and base peak $m / z=343$ support the loss of $\mathrm{HBr}$ molecule.

\section{X-ray structure of compound $8 a$}

Also, the structures were unambiguously confirmed from X-ray obtained for the compound 4-phenyl2,3-bis(phenylamino)thiazol-3-ium bromide (8a; Fig. 3 and Tables 15-21; note that the crystallographic numbering does not correspond to the systematic IUPAC numbering rules). The thiazole ring is planar (mean deviation from the L.S.-plane S1, C2, N3 C4, C5 $0.0036 \AA$ ), while the phenyl substituent and the two NHPh moieties are twisted or orthogonal in respect to the thiazole ring (angle between the L.S. planes $42.44(6)^{\circ}$ for $\mathrm{C} 41 \ldots \mathrm{C} 46,57.92(6)^{\circ}$ for $\mathrm{N} 21$ and $84.00(5)^{\circ}$ for $\left.\mathrm{N} 31\right)$.
Plausible mechanism for the formation of 2,3,4-trisubstituted thiazolium bromides 8a-8e

According to the above results, proposed mechanism for the formation of 4-aryl-2-amino-3-(phenylamino)thiazol-3-ium bromide derivatives 8a-8e is illustrated in Scheme 4. This showed that the heterocyclization takes place via sulfur atom and $\mathrm{N}^{2}$ due to their high nucleophilicity (Scheme 4).

\section{Optimization of the reaction conditions between thiosemicarbazides and phenacyl bromides}

Therefore, the optimized reaction conditions involved mixing equimolar amounts of compound $\mathbf{1 a}-\mathbf{1 d}$ or $\mathbf{7 a}-\mathbf{7 e}$ and 2a, 2b at room temperature in ethyl acetate (as dipolar aprotic solvent). The solvent, temperature, and the molar ratio of the reactants may all play a critical role on the reaction pathway and these variables were investigated. Different solvents such as tetrahydrofuran (THF), 1,2-dichloroethane, and acetonitrile were studied, but ethyl acetate proved to be the selective solvent. The main factor that controls the process to obtain the target products is to carry out the reactions at room temperature and ethyl acetate was the best solvent chosen to get high yields.

Increasing the amounts of compound $1 \mathbf{a}-\mathbf{1 d}$ or $\mathbf{7 a}-7 \mathbf{e}$ showed that there were no needs to improve the yields of products. The effect of different basic media was investigated, and ethyl acetate without any additive showed high activity.

Scheme 3<smiles>[R]NC(=S)NNc1ccccc1</smiles>

$7 a-7 e$<smiles>O=C(CBr)c1ccccc1</smiles>

2a<smiles>[R]Nc1scc(-c2ccc(CC(C)C)cc2)[n+]1Nc1ccccc1</smiles> 


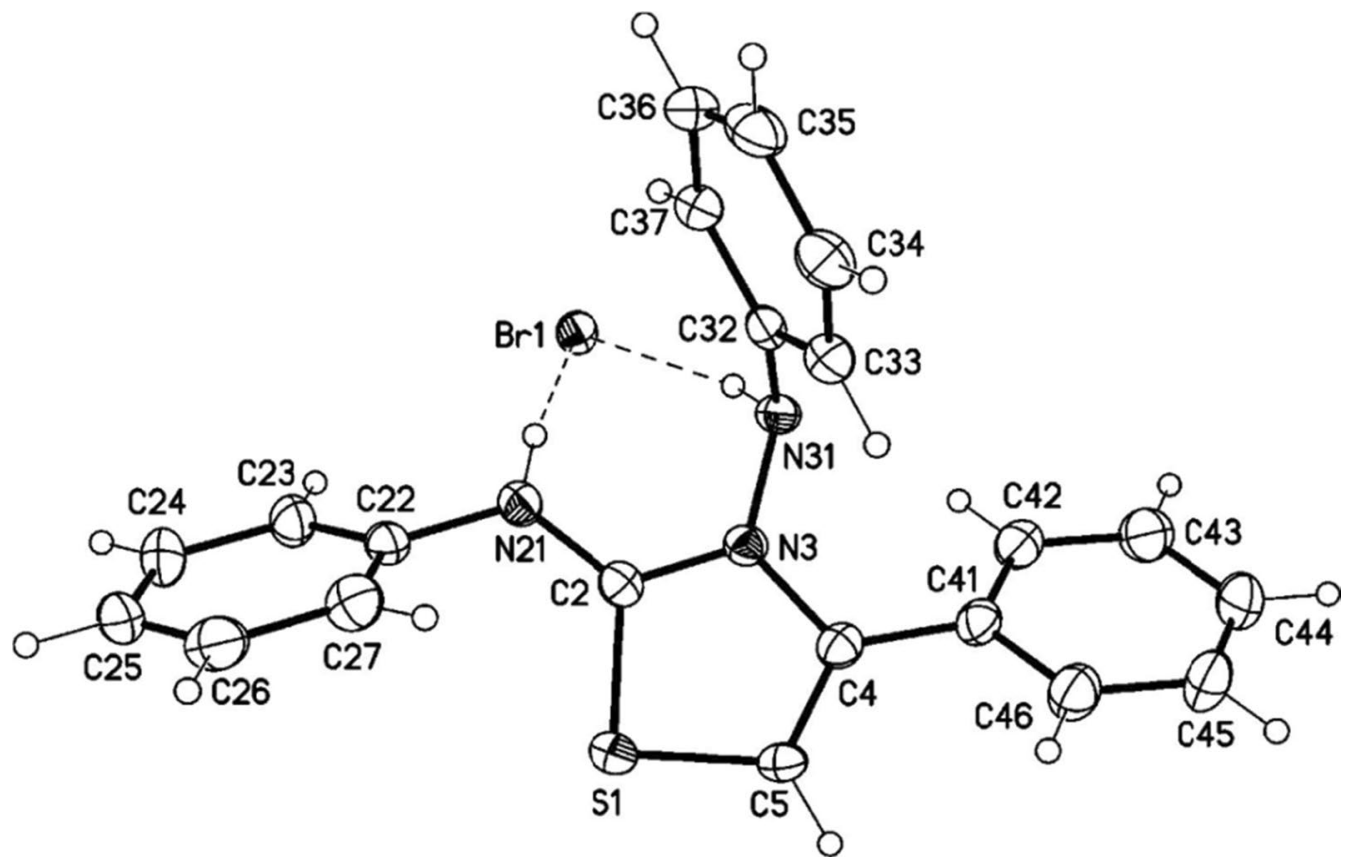

Fig. 3 Molecular X-ray structure of 4-phenyl-2,3-bis(phenylamino)thiazol-3-ium bromide (8a)

Scheme 4<smiles>[R]NC(=S)NNc1ccccc1</smiles><smiles>[R]N=C(S)NNc1ccccc1</smiles><smiles>[R]Nc1scc(-c2ccccc2)[n+]1Nc1ccccc1</smiles>

$8 a-8 e$<smiles>O=C(CBr)c1ccccc1</smiles><smiles></smiles>

$+\mathrm{HBr}$



$\mathrm{Ph}$<smiles>[R]N=c1scc(P)n1Nc1ccccc1</smiles>

11<smiles>[R]N=C(SCC(=O)CCC)[NH+]1CCCCCC1(O)c1ccccc1</smiles>

9<smiles>[3H][3H]</smiles><smiles>[R]N=C1SCC(O)(c2ccccc2)N1Nc1ccccc1</smiles>

10

\section{Conclusion}

Our studies resulted in the construction of novel two groups of substituted thiazolium salts 2,4-disubstituted and 2,3,4-trisubstituted thiazolium bromide derivatives in high yields via one step reaction and at ambient temperature in the presence of ethyl acetate as solvent. Simple and efficient procedures were used to synthesize the thiazolium bromides. 
Table 1 Optimization of reaction conditions for the formation of $\mathbf{3 a}$ and $8 \mathbf{a}$

\begin{tabular}{llll}
\hline Entry & Solvent & Yield of $\mathbf{3 a} / \%$ & Yield of $\mathbf{8 a} / \%$ \\
\hline 1 & Tetrahydrofuran & 34 & 29 \\
2 & 1,2-Dichloroethane & 46 & 36 \\
3 & Acetonitrile & 39 & 32 \\
4 & Ethyl acetate & 90 & 93 \\
\hline
\end{tabular}

\section{Experimental}

Gallenkamp melting point apparatus was used to determine the melting points. IR spectra were recorded with Alpha, Bruker FT-IR instruments using potassium bromide pellets. NMR spectra were recorded for ${ }^{1} \mathrm{H}$ NMR at $400 \mathrm{MHz}$ and ${ }^{13} \mathrm{C} \mathrm{NMR}$ at $100 \mathrm{MHz}$ on a Bruker AM 400 spectrometrer with TMS as internal standard $(\delta=0 \mathrm{ppm})$, and data are reported as follows: chemical shift, multiplicity ( $s=$ singlet, $\mathrm{t}=$ triplet, $\mathrm{q}=$ quartet, $\mathrm{m}=$ multiplet, and $\mathrm{br}=$ broad). For ${ }^{13} \mathrm{C}$ NMR, spectra were obtained with complete proton decoupling. Finnigan MAT instrument was used to record the mass spectra (70 eV, EI-mode). Elemental analyses for C, H, N, and $\mathrm{S}$ were carried out using an Elmer 306.

Mono and di-substituted thiosemicarbazides were prepared according to literature methods (1a [24], 1b [25], 1c [26], 1d [27], 7a-7e [28]). Phenacyl bromides 2a, 2b were prepared according to literature [29, 30].

\section{Synthesis of 4-substituted 2-(2-hydrazinyl) thiazol-3-ium bromides $3 a-3 g$}

A solution of $1.0 \mathrm{mmol}$ of $\mathrm{N}$-substituted thiosemicarbazides 1a-1d in $15 \mathrm{~cm}^{3}$ ethyl acetate was added to $1.0 \mathrm{mmol}$ of phenacyl bromides $\mathbf{2 a}, \mathbf{2 b}$ dissolved in $10 \mathrm{~cm}^{3}$ ethyl acetate. The mixture was stirred for $30 \mathrm{~min}$ and allowed to stand overnight, after completion of the reaction; the formed precipitate was filtered, washed several times with ethyl acetate to afford the target products $\mathbf{3 a - 3 g}$ (yields 84-93\%).

2-[2-(2,4-Dinitrophenyl)hydrazinyl]-4-phenylthiazol-3-ium bromide $\left(\mathrm{C}_{15} \mathrm{H}_{12} \mathrm{BrN}_{5} \mathrm{O}_{4} \mathrm{~S}, 3 \mathrm{a}\right)$ Orange crystals (acetonitrile); yield $0.394 \mathrm{~g}(90 \%)$; m.p.: $202-204{ }^{\circ} \mathrm{C} ;{ }^{1} \mathrm{H}$ NMR $(400 \mathrm{MHz}$, DMSO- $\left.d_{6}\right): \delta=7.21-7.40(\mathrm{~m}, 5 \mathrm{H}, \mathrm{Ar}-\mathrm{H}), 7.48-7.55(\mathrm{~m}, 1 \mathrm{H}$, $\mathrm{Ar}-\mathrm{H}), 7.82(\mathrm{~s}, 1 \mathrm{H}$, thiazole-H), 8.34-8.43 (m, 1H, Ar-H), 8.83-8.92 (m, 1H, Ar-H), 10.20 (br, s, 1H, NH), 10.63 (br, $\mathrm{s}, 1 \mathrm{H}, \mathrm{NH}) \mathrm{ppm} ;{ }^{13} \mathrm{C}$ NMR $\left(100 \mathrm{MHz}\right.$, DMSO- $\left.d_{6}\right): \delta=115.6$ (C-5), 123.9, 125.5, 127.6, 128.6, 130.0, $130.4(\mathrm{Ar}-\mathrm{CH})$, 131.3, 134.8, 136.4, 148.6 (Ar-C), 150.5 (C-4), 170.5 (C-2) ppm; IR (KBr): $\bar{v}=3220(\mathrm{NH}), 3102(\mathrm{Ar}-\mathrm{CH}), 1611(\mathrm{C}=\mathrm{N})$, $1591(\mathrm{Ar}-\mathrm{C}=\mathrm{C}), 1528$ and $1335\left(\mathrm{NO}_{2}\right) \mathrm{cm}^{-1}$; $\mathrm{MS}(70 \mathrm{eV})$ : $m / z=439 / 441\left(\mathrm{M}^{+}, 6\right), 357\left(\mathrm{M}^{+}-\mathrm{HBr}, 28\right), 257$ (10), 191 (15), 168 (46), 153 (100), 105 (18), 91 (25).
4-Phenyl-2-(2-phenylhydrazinyl)thiazol-3-ium bromide $\left(\mathrm{C}_{15} \mathrm{H}_{12} \mathrm{BrN}_{5} \mathrm{O}_{4} \mathrm{~S}, 3 \mathrm{~b}\right)$ Colorless crystals (acetonitrile); yield 0.309 g (89\%); m.p.: $152-153{ }^{\circ} \mathrm{C}$; ${ }^{1} \mathrm{H}$ NMR $(400 \mathrm{MHz}$, DMSO- $\left.d_{6}\right): \delta=7.36-7.48(\mathrm{~m}, 4 \mathrm{H}, \mathrm{Ar}-\mathrm{H}), 7.61-7.70(\mathrm{~m}$, $3 \mathrm{H}, \mathrm{Ar}-\mathrm{H}$ and thiazole- $\mathrm{H}), 7.97-8.08(\mathrm{~m}, 5 \mathrm{H}, \mathrm{Ar}-\mathrm{H}$ and $\mathrm{NH}), 8.39$ (br, s, NH) ppm; ${ }^{13} \mathrm{C}$ NMR (100 MHz, DMSO$\left.d_{6}\right): \delta=117.6(\mathrm{C}-5), 123.5,125.9,128.6,129.0,129.9,133.4$ (Ar-CH), 133.5, 155.1 (Ar-C), 150.9 (C-4), 175.4 (C-2) ppm; IR (KBr): $\bar{v}=3175(\mathrm{NH}), 3097(\mathrm{Ar}-\mathrm{CH}), 1618(\mathrm{C}=\mathrm{N})$, $1577(\mathrm{Ar}-\mathrm{C}=\mathrm{C}) \mathrm{cm}^{-1} ; \mathrm{MS}(70 \mathrm{eV}): \mathrm{m} / z=347 / 349\left(\mathrm{M}^{+}, 9\right)$, 267 (M+-HBr, 100), 191 (33), 167 (22), 105 (55), 77 (13).

2-[2-(3-Chlorophenyl)hydrazinyl]-4-phenylthiazol-3-ium bromide $\left(\mathrm{C}_{15} \mathrm{H}_{13} \mathrm{BrClN}_{3} \mathrm{~S}, 3 \mathrm{c}\right)$ Colorless crystals (acetonitrile); yield $0.329 \mathrm{~g}(86 \%)$; m.p.: $163-164{ }^{\circ} \mathrm{C}$; ${ }^{1} \mathrm{H}$ NMR $(400 \mathrm{MHz}$, DMSO- $\left.d_{6}\right): \delta=6.98-7.22(\mathrm{~m}, 3 \mathrm{H}, \mathrm{Ar}-\mathrm{H}$ and thiazole-H), 7.39-7.52 (m, 2H, Ar-H and NH), 7.64-7.71 (m, 2H, Ar-H), 7.91-8.07 (m, 4H, Ar-H), 8.45 (br, s, $1 \mathrm{H}, \mathrm{NH}) \mathrm{ppm} ;{ }^{13} \mathrm{C} \mathrm{NMR}$ $\left(100 \mathrm{MHz}, \mathrm{DMSO}-d_{6}\right): \delta=117.9(\mathrm{C}-5), 122.3,123.3,125.5$, 128.8, 129.2, 131.5, 132.2 (Ar-CH), 133.6, 134.8, 155.4 (Ar-C), 151.7 (C-4), 175.1 (C-2) ppm; IR (KBr): $\bar{v}=3215$ $(\mathrm{NH}), 3087(\mathrm{Ar}-\mathrm{CH}), 1621(\mathrm{C}=\mathrm{N}), 1589(\mathrm{Ar}-\mathrm{C}=\mathrm{C}) \mathrm{cm}^{-1}$; MS (70 eV): $m / z=383 / 387\left(\mathrm{M}^{+}, 5\right), 303(33), 301\left(\mathrm{M}^{+}-\mathrm{HBr}, 100\right)$, 191 (22), 161 (23), 141 (29), 113 (47), 111 (15).

4-Phenyl-2-(2-tosylhydrazinyl)thiazol-3-ium bromide $\left(\mathrm{C}_{16} \mathrm{H}_{16} \mathrm{BrN}_{3} \mathrm{O}_{2} \mathrm{~S}_{2}, 3 \mathrm{~d}\right)$ Red crystals (acetonitrile); yield 0.396 g (93\%); m.p.: $185-186{ }^{\circ} \mathrm{C} ;{ }^{1} \mathrm{H}$ NMR $(400 \mathrm{MHz}$, DMSO- $\left.d_{6}\right): \delta=2.35$ (s, $\left.3 \mathrm{H}, \mathrm{CH}_{3}\right), 7.35-7.41(\mathrm{~m}, 3 \mathrm{H}, \mathrm{Ar}-\mathrm{H})$, 7.50-7.62 (m, 5H, Ar-H and thiazole-H), 7.66-7.73 (m, $2 \mathrm{H}, \mathrm{Ar}-\mathrm{H}), 10.02$ (br, s, 1H, NH), 10.33 (br, s, 1H, NH) ppm; ${ }^{13} \mathrm{C}$ NMR (100 MHz, DMSO- $\left.d_{6}\right): \delta=20.9\left(\mathrm{CH}_{3}\right)$, 114.6 (C-5), 127.5, 128.7, 129.8, 130.0, $130.9(\mathrm{Ar}-\mathrm{CH})$, 133.3, 134.9, 144.8 (Ar-C), 151.8 (C-4), 174.3 (C-2) ppm; IR (KBr): $\bar{v}=3156(\mathrm{NH}), 3086(\mathrm{Ar}-\mathrm{CH}), 2982$ and 2832 (ali-CH), $1597(\mathrm{Ar}-\mathrm{C}=\mathrm{C}) \mathrm{cm}^{-1}$; MS $(70 \mathrm{eV}): \mathrm{m} / \mathrm{z}=425 / 427$ $\left(\mathrm{M}^{+}, 8\right), 345$ ( $\left.\mathrm{M}^{+}-\mathrm{HBr}, 100\right), 191$ (24), 185 (33), 161 (43), 155 (65), 105 (8), 91 (6).

4-(4-Bromophenyl)-2-(2-phenylhydrazinyl)thiazol-3-ium bromide $\left(\mathrm{C}_{15} \mathrm{H}_{13} \mathrm{Br}_{2} \mathrm{~N}_{3} \mathrm{~S}\right.$, 3e) Colorless crystals (acetonitrile); yield $0.371 \mathrm{~g} \mathrm{(87 \% );} \mathrm{m.p.:} 176-177{ }^{\circ} \mathrm{C} ;{ }^{1} \mathrm{H}$ NMR $(400 \mathrm{MHz}$, DMSO- $\left.d_{6}\right): \delta=7.48-7.52$ (m, 3H, Ar-H and NH), 7.62-7.70 (m, 3H, Ar-H and NH), 8.00-8.18 (m, 5H, Ar-H), 8.48 (br, s, NH) ppm; ${ }^{13} \mathrm{C}$ NMR $\left(100 \mathrm{MHz}\right.$, DMSO- $\left.d_{6}\right): \delta=114.6$ (C-5), 118.3, 122.9, 129.6, 130.7, 132.7 (Ar-CH), 123.5, 127.9, 149.9 (Ar-C), 150.9 (C-4), 175.5 (C-2) ppm; IR $(\mathrm{KBr}): \bar{v}=3241(\mathrm{NH}), 3054(\mathrm{Ar}-\mathrm{CH}), 2925($ ali-CH), 1623 $(\mathrm{C}=\mathrm{N}), 1597(\mathrm{Ar}-\mathrm{C}=\mathrm{C}) \mathrm{cm}^{-1}$; MS $(70 \mathrm{eV}): \mathrm{m} / \mathrm{z}=427 / 431$ $\left(\mathrm{M}^{+}, 3\right), 347 / 349$ ( $\left.\mathrm{M}^{+}-\mathrm{HBr}, 100\right), 271 / 273$ (33), 241/243 (46), 181/183 (25), 167 (7), 107 (20), 77 (55). 
4-(4-Bromophenyl)-2-[2-(3-chlorophenyl)hydrazinyl]thiazol-3-ium bromide $\left(\mathrm{C}_{15} \mathrm{H}_{12} \mathrm{Br}_{2} \mathrm{CIN}_{3} \mathrm{~S}, 3 \mathrm{f}\right)$ Colorless crystals (acetonitrile); yield $0.387 \mathrm{~g} \mathrm{(84 \% );} \mathrm{m.p.:} 190-191{ }^{\circ} \mathrm{C} ;{ }^{1} \mathrm{H}$ NMR (400 MHz, DMSO- $\left.d_{6}\right): \delta=6.93-7.10(\mathrm{~m}, 4 \mathrm{H}, \mathrm{Ar}-\mathrm{H}$ and thiazol-H), 7.37-7.51 (m, 2H, Ar-H and NH), 7.65$7.73(\mathrm{~m}, 1 \mathrm{H}, \mathrm{Ar}-\mathrm{H}), 7.94-8.05$ (m, 3H, Ar-H), 8.45 (br, s, $1 \mathrm{H}, \mathrm{NH}) \mathrm{ppm} ;{ }^{13} \mathrm{C}$ NMR $\left(100 \mathrm{MHz}, \mathrm{DMSO}-d_{6}\right): \delta=119.1$ (C-5), 122.2, 124.3, 128.9, 129.6, 130.8, $132.4(\mathrm{Ar}-\mathrm{CH})$, 123.0, 128.0, 134.5, 149.7 (Ar-C), 151.8 (C-4), 175.6 (C-2) ppm; IR (KBr): $\bar{v}=3210(\mathrm{NH}), 3099(\mathrm{Ar}-\mathrm{CH}), 1617(\mathrm{C}=\mathrm{N})$, $1591(\mathrm{Ar}-\mathrm{C}=\mathrm{C}) \mathrm{cm}^{-1}$; $\mathrm{MS}(70 \mathrm{eV}): \mathrm{m} / z=461 / 467\left(\mathrm{M}^{+}, 6\right)$, 381/385 ( $\left.\mathrm{M}^{+}-\mathrm{HBr}, 100\right), 269 / 271$ (52), 201 (13), 181/183 (41), 111/112 (71), 105 (83).

4-(4-Bromophenyl)-2-(2-tosylhydrazinyl)thiazol-3-ium bromide $\left(\mathrm{C}_{16} \mathrm{H}_{15} \mathrm{Br}_{2} \mathrm{~N}_{3} \mathrm{O}_{2} \mathrm{~S}_{2}, 3 \mathrm{~g}\right)$ Violet crystals (acetonitrile); yield $0.439 \mathrm{~g}(87 \%)$; m.p.: $213-215^{\circ} \mathrm{C} ;{ }^{1} \mathrm{H}$ NMR $(400 \mathrm{MHz}$, DMSO- $\left.d_{6}\right): \delta=2.38$ (s, 3H, $\left.\mathrm{CH}_{3}\right), 7.38-7.43(\mathrm{~m}, 2 \mathrm{H}, \mathrm{Ar}-\mathrm{H})$, 7.48-7.57 (m, 5H, Ar-H and thiazole-H), 7.69-7.74 (m, 2H, Ar-H), 10.04 (br, s, 1H, NH), 10.31 (br, s, 1H, NH) ppm; ${ }^{13} \mathrm{C}$ NMR (100 MHz, DMSO- $\left.d_{6}\right): \delta=20.9\left(\mathrm{CH}_{3}\right), 112.4(\mathrm{C}-5)$, 127.8, 129.6, 130.2, 130.5 (Ar-CH), 121.9, 133.3, 135.0, 144.8 (Ar-C), 151.8 (C-4), 173.9 (C-2) ppm; IR (KBr): $\bar{v}=3225(\mathrm{NH}), 3094(\mathrm{Ar}-\mathrm{CH}), 1615(\mathrm{C}=\mathrm{N}), 1590(\mathrm{Ar}-\mathrm{C}=\mathrm{C})$ and 1523 and $1333\left(\mathrm{NO}_{2}\right) \mathrm{cm}^{-1}$; $\mathrm{MS}(70 \mathrm{eV}): \mathrm{m} / z=505 / 509$ $\left(\mathrm{M}^{+}, 12\right), 425 / 427$ ( $\left.\mathrm{M}^{+}-\mathrm{HBr}, 100\right), 269 / 271$ (15), 241/243 (12), 183 (35), 181 (15), 155 (55), 91 (90), 77 (50).

\section{Synthesis of 4-aryl-2-amino-3-(phenylamino)- thiazol-3-ium bromide derivatives 8a-8e}

To a stirred solution of $0.198 \mathrm{~g}$ phenacyl bromide 2a $(1.0 \mathrm{mmol})$ in $10 \mathrm{~cm}^{3}$ ethyl acetate a solution of appropriate 1-phenyl-4-substituted thiosemicarbazides $7 \mathbf{a}-7 \mathbf{e}$ $(1.0 \mathrm{mmol})$ in $15 \mathrm{~cm}^{3}$ ethyl acetate was added portion wise and the mixture allowed to stirred at room temperature. During the stirring a precipitate was formed after a few minutes. The reaction mixture was left overnight, and the precipitate was collected through filtration, washed with ethyl acetate several times to obtain the final products $\mathbf{8 a}-\mathbf{8 e}$ in high purity and in good yields (88-97\%).

\section{4-Phenyl-2,3-bis(phenylamino)thiazol-3-ium bromide} $\left(\mathrm{C}_{21} \mathrm{H}_{18} \mathrm{BrN}_{3} \mathrm{~S}, 8 \mathrm{a}\right)$ Colorless crystals (acetonitrile); yield $0.394 \mathrm{mg}$ (93\%); m.p.: $165-167{ }^{\circ} \mathrm{C} ;{ }^{1} \mathrm{H}$ NMR $(400 \mathrm{MHz}$, DMSO- $\left.d_{6}\right): \delta=6.60-6.68(\mathrm{~m}, 2 \mathrm{H}, \mathrm{Ar}-\mathrm{H}), 6.78-6.82(\mathrm{~m}$, $1 \mathrm{H}, \mathrm{Ar}-\mathrm{H}), 7.10-7.15$ (m, 2H, Ar-H and thiazole-H), 7.28$7.70(\mathrm{~m}, 12 \mathrm{H}, \mathrm{Ar}-\mathrm{H}$ and $\mathrm{NH}), 9.88(\mathrm{br}, \mathrm{s}, 1 \mathrm{H}, \mathrm{NH}) \mathrm{ppm}$; ${ }^{13} \mathrm{C}$ NMR (100 MHz, DMSO- $\left.d_{6}\right): \delta=112.7$ (C-5), 121.5, 123.6, 128.2, 128.5, 128.8, 129.0, 129.2, 129.9, 130.2 (Ar$\mathrm{CH}), 138.0$ (C-4), 127.3, 141.1, 144.0 (Ar-C), 168.6 (C-2) ppm; IR (KBr): $\bar{v}=3276(\mathrm{NH}), 3020-3110(\mathrm{Ar}-\mathrm{CH}), 1595$
$(\mathrm{Ar}-\mathrm{C}=\mathrm{C}) \mathrm{cm}^{-1} ; \mathrm{MS}(70 \mathrm{eV}): \mathrm{m} / \mathrm{z}=425 / 427\left(\mathrm{M}^{+}, 4\right), 343$ (M+ $\left.{ }^{+}-\mathrm{HBr}, 100\right), 253$ (40), 209 (3), 135 (18), 93 (5), 77 (57).

2-(Allylamino)-4-phenyl-3-(phenylamino)thiazol-3-ium bromide $\left(\mathrm{C}_{18} \mathrm{H}_{18} \mathrm{BrN}_{3} \mathrm{~S}, 8 \mathrm{~b}\right)$ Colorless crystals (acetonitrile); yield $0.376 \mathrm{~g}(97 \%)$; m.p.: $182-183{ }^{\circ} \mathrm{C} ;{ }^{1} \mathrm{H}$ NMR $\left(400 \mathrm{MHz}, \mathrm{DMSO}-d_{6}\right): \delta=5.08-5.12\left(\mathrm{~m}, 4 \mathrm{H}\right.$, allyl $\left.-\mathrm{CH}_{2} \mathrm{~N}\right)$, 5.15-5.22 (allyl- $\left.\mathrm{CH}_{2}=\right), 5.72-5.82(\mathrm{~m}, 1 \mathrm{H}$, allyl- $\mathrm{CH}=)$, 6.80-6.86 (m, 2H, Ar-H and thiazole-H), 6.92-6.98 (m, 3H, $\mathrm{Ar}-\mathrm{H}), 7.12-7.15$ (m, 3H, Ar-H), 7.42-7.52 (m, 4H, Ar-H and $\mathrm{NH}), 9.42(\mathrm{br}, \mathrm{s}, 1 \mathrm{H}, \mathrm{NH}) \mathrm{ppm} ;{ }^{13} \mathrm{C}$ NMR $(100 \mathrm{MHz}$, DMSO- $\left.d_{6}\right): \delta=64.6\left(\right.$ allyl- $\left.\mathrm{CH}_{2} \mathrm{~N}\right), 113.6(\mathrm{C}-5), 118.8$ (allyl$\left.\mathrm{CH}_{2}=\right), 122.5,127.2,129 ., 129.4,129.8,130.7(\mathrm{Ar}-\mathrm{CH})$, 134.7 (allyl-CH=), $139.6(\mathrm{C}-4), 142.3,145.0(\mathrm{Ar}-\mathrm{C}), 172.9$ (C-2) ppm; IR (KBr): $\bar{v}=3280(\mathrm{NH}), 3025-3115(\mathrm{Ar}-\mathrm{CH})$, 2990 and 2946 (ali-CH), $1598(\mathrm{Ar}-\mathrm{C}=\mathrm{C}) \mathrm{cm}^{-1}$; MS $(70 \mathrm{eV})$ : $m / z=387 / 389\left(\mathrm{M}^{+}, 9\right), 307\left(\mathrm{M}^{+}-\mathrm{HBr}, 100\right), 253$ (38), 209 (36), 99 (51), 93 (58).

2-(Ethylamino)-4-phenyl-3-(phenylamino)thiazol-3-ium bromide $\left(\mathrm{C}_{17} \mathrm{H}_{18} \mathrm{BrN}_{3} \mathrm{~S}, 8 \mathrm{c}\right)$ Colorless crystals (acetonitrile); yield $0.353 \mathrm{~g}(94 \%)$; m.p.: $157-158{ }^{\circ} \mathrm{C} ;{ }^{1} \mathrm{H}$ NMR $(400 \mathrm{MHz}$, DMSO- $\left.d_{6}\right): \delta=1.12-1.18\left(\mathrm{t}, 3 \mathrm{H}, J=6.77 \mathrm{~Hz}, \mathrm{CH}_{3}\right), 3.96-$ 4.08 (q, $\left.2 \mathrm{H}, J=6.77 \mathrm{~Hz}, \mathrm{CH}_{2}\right), 6.90-7.00(\mathrm{~m}, 3 \mathrm{H}, \mathrm{Ar}-\mathrm{H}$ and thiazole-H), 7.12 (br, s, 1H, NH), 7.25-7.33 (m, 3H, Ar-H), 7.50-7.68 (m, 5H, Ar-H), 9.32 (br, s, $1 \mathrm{H}, \mathrm{NH}) \mathrm{ppm} ;{ }^{13} \mathrm{C}$ NMR $\left(100 \mathrm{MHz}, \mathrm{DMSO}-d_{6}\right): \delta=13.0\left(\mathrm{CH}_{3}\right), 42.7\left(\mathrm{CH}_{2}\right)$, 113.4 (C-5), 121.4, 126.5, 127.4, 129.2, 129.8, 130.4 (ArCH), 139.6 (C-4), 142.0, 145.9 (Ar-C), 172.8 (C-2) ppm; IR $(\mathrm{KBr}): \bar{v}=3265(\mathrm{NH}), 3023-3112(\mathrm{Ar}-\mathrm{CH}), 2989$ and 2940 (ali-CH), $1597(\mathrm{Ar}-\mathrm{C}=\mathrm{C}) \mathrm{cm}^{-1}$; MS $(70 \mathrm{eV}): \mathrm{m} / z=375 / 377$ $\left(\mathrm{M}^{+}, 11\right), 295$ (100), 253 (45), 209 (88), 195 (52), 102 (25), 93 (41), 87 (29).

2-(Cyclohexylamino)-4-phenyl-3-(phenylamino)thiazol-3-ium bromide $\left(\mathrm{C}_{21} \mathrm{H}_{24} \mathrm{BrN}_{3} \mathrm{~S}\right.$, 8d) Colorless crystals (acetonitrile); yield $0.387 \mathrm{~g}(90 \%)$; m.p.: $173-174{ }^{\circ} \mathrm{C} ;{ }^{1} \mathrm{H}$ NMR $\left(400 \mathrm{MHz}, \mathrm{DMSO}-d_{6}\right): \delta=1.07-2.10(\mathrm{~m}, 10 \mathrm{H}$, cyclohexyl$\mathrm{CH}_{2}$ ), 3.75-3.93 (m, 1H, cyclohexyl-CH), 6.60-6.75 (m, $3 \mathrm{H}, \mathrm{Ar}-\mathrm{H}$ and thiazole-H), 6.90-7.06 (m, 3H, Ar-H), 7.32$7.58(\mathrm{~m}, 3 \mathrm{H}, \mathrm{Ar}-\mathrm{H}), 7.80-7.91$ (m, 2H, Ar-H), 8.36 (br, s, $1 \mathrm{H}, \mathrm{NH}), 9.80$ (br, s, 1H, NH) ppm; ${ }^{13} \mathrm{C} \mathrm{NMR}(100 \mathrm{MHz}$, DMSO- $\left.d_{6}\right): \delta=23.8,31.8,41.3\left(\right.$ cyclohexyl- $\left.\mathrm{CH}_{2}\right), 58.6$ (cyclohexyl-CH), 116.0 (C-5), 122.5, 126.4, 127.7, 128.8, 129.4, 130.7 (Ar-CH), 137.9 (C-4), 143.8, 144.3 (Ar-C), $173.9(\mathrm{C}-2)$ ppm; IR (KBr): $\bar{v}=3269(\mathrm{NH}), 3018-3115(\mathrm{Ar}-$ $\mathrm{CH}), 2996$ and 2943 (ali-CH), $1591(\mathrm{Ar}-\mathrm{C}=\mathrm{C}) \mathrm{cm}^{-1}$; MS $(70 \mathrm{eV}): \mathrm{m} / z=429 / 431\left(\mathrm{M}^{+}, 5\right), 349\left(\mathrm{M}^{+}-\mathrm{HBr}, 100\right), 253$ (52), 247 (36), 209 (21), 141 (33), 102 (31), 93 (36), 91 (62).

2-(Benzylamino)-4-phenyl-3-(phenylamino)thiazol-3-ium bromide $\left(\mathrm{C}_{22} \mathrm{H}_{20} \mathrm{BrN}_{3} \mathrm{~S}, 8 \mathrm{8}\right)$ Colorless crystals (acetonitrile); yield $0.386 \mathrm{mg}$ (88\%); m.p.: $194-195{ }^{\circ} \mathrm{C} ;{ }^{1} \mathrm{H}$ NMR 
(400 MHz, DMSO- $d_{6}$ ): $\delta=5.40$ (s, 2H, $\mathrm{CH}_{2}$-benzyl), 6.72$6.78(\mathrm{~m}, 2 \mathrm{H}, \mathrm{Ar}-\mathrm{H}), 6.88-6.92(\mathrm{~m}, 1 \mathrm{H}, \mathrm{Ar}-\mathrm{H}), 7.02-7.06$ $(\mathrm{m}, 2 \mathrm{H}, \mathrm{Ar}-\mathrm{H}), 7.20-7.28(\mathrm{~m}, 3 \mathrm{H}, \mathrm{Ar}-\mathrm{H}$, and thiazole- $\mathrm{H})$, 7.35-7.43 (m, 3H, Ar-H), 7.46-7.60 (m, 6H, Ar-H and NH), $9.20(\mathrm{br}, \mathrm{s}, 1 \mathrm{H}, \mathrm{NH}) \mathrm{ppm} ;{ }^{13} \mathrm{C}$ NMR $\left(100 \mathrm{MHz}, \mathrm{DMSO}-d_{6}\right)$ : $\delta=49.9\left(\mathrm{CH}_{2}\right.$-benzyl), $113.4(\mathrm{C}-5), 121.4,126.2,128.3$, $128.9,129.0,129.2,129.5,130.3(\mathrm{Ar}-\mathrm{CH}), 138.5(\mathrm{C}-4)$, $173.3(\mathrm{C}-2) \mathrm{ppm}$; IR (KBr): $\bar{v}=3270(\mathrm{NH}), 3028-3109(\mathrm{Ar}-$ $\mathrm{CH}), 2988$ and 2938 (ali-CH), $1598(\mathrm{Ar}-\mathrm{C}=\mathrm{C}) \mathrm{cm}^{-1}$; MS $(70 \mathrm{eV}): \mathrm{m} / z=437 / 439\left(\mathrm{M}^{+}, 10\right), 357\left(\mathrm{M}^{+}-\mathrm{HBr}, 100\right), 253$ (47), 209 (11), 149 (21), 93 (5), 91 (87), 77 (51).

\section{Single crystal $\mathrm{X}$-ray structure determination of 3a, 3d, and 8a}

The single-crystal X-ray diffraction study was carried out on a Bruker D8 Venture diffractometer with Photon II detector at $123(2) \mathrm{K}$ using $\mathrm{Cu}-\mathrm{K} \alpha$ radiation $(\lambda=1.54178 \AA)$. Dual space methods (SHELXT) [31] were used for structure solution and refinement was carried out using SHELXL-2014 (full-matrix least-squares on $F^{2}$ ) [32]. Hydrogen atoms were refined using a riding model $(\mathrm{H}(\mathrm{N})$ free). Semi-empirical absorption corrections were applied.

Compound 3a: $\mathrm{C}_{15} \mathrm{H}_{12} \mathrm{~N}_{5} \mathrm{O}_{4} \mathrm{~S} \cdot \mathrm{Br}, M=438.27 \mathrm{~g} \mathrm{~mol}^{-1}$, orange crystals, size $0.18 \times 0.14 \times 0.04 \mathrm{~mm}$, monoclinic, space group $P 2 / c$ (no.14), $a=15.2596(8) \AA, b=15.8466(8)$ $\AA, c=7.1347(4) \AA, \beta=94.047(2)^{\circ}, V=1720.96(16) \AA^{3}$, $Z=4, D_{\text {calcd }}=1.692 \mathrm{Mg} \mathrm{m}^{-3}, \mathrm{~F}(000)=880, \mu=4.70 \mathrm{~mm}^{-1}$, $T=123 \mathrm{~K}, 18,164$ measured reflections $\left(2 \theta_{\max }=144.2^{\circ}\right)$, 3383 independent $\left[R_{\mathrm{int}}=0.027\right], 244$ parameters, 3 restraints, $R_{l}$ [for $\left.3226 I>2 \sigma(I)\right]=0.024, w R^{2}$ (for all data) $=0.065$, $S=1.05$, largest diff. peak and hole $=0.45 \mathrm{e}^{-3} /-0.21$ e $\AA^{-3}$.

Compound 3d: $\mathrm{C}_{16} \mathrm{H}_{16} \mathrm{~N}_{3} \mathrm{O}_{2} \mathrm{~S}_{2} \cdot \mathrm{Br}, M=426.35 \mathrm{~g} \mathrm{~mol}^{-1}$, red crystals, size $0.12 \times 0.06 \times 0.04 \mathrm{~mm}$, orthorhombic, space group Pbca (no.62), $a=12.5822(5) \AA$, $b=15.4936(6) \AA, c=18.1813(8) \AA, V=3544.3(3) \AA^{3}$, $Z=8, D_{\text {calcd }}=1.598 \mathrm{Mg} \mathrm{m}^{-3}, \mathrm{~F}(000)=1728, \mu=5.49 \mathrm{~mm}^{-1}$, $T=123 \mathrm{~K}, 36,334$ measured reflections $\left(2 \theta_{\max }=144.4^{\circ}\right)$, 3499 independent $\left[R_{\text {int }}=0.032\right], 227$ parameters, 3 restraints, $R_{1}[$ for $3340 I>2 \sigma(I)]=0.024, w R^{2}$ (for all data) $=0.064$, $S=1.04$, largest diff. peak and hole $=0.60$ e $\AA^{-3} /-0.40$ e $\AA^{-3}$.

Compound 8a: $\mathrm{C}_{21} \mathrm{H}_{18} \mathrm{~N}_{3} \mathrm{~S} \cdot \mathrm{Br}, M=424.35 \mathrm{~g} \mathrm{~mol}^{-1}$, colourless crystals, size $0.36 \times 0.24 \times 0.16 \mathrm{~mm}$, monoclinic, space group $P 2{ }_{1} / \mathrm{c}$ (no.14), $a=10.7239(4) \AA, b=10.5069$ (4) $\AA$, $c=16.6705(7) \AA, \beta=90.611(1)^{\circ}, V=1878.24(13) \AA^{3}$, $Z=4, D_{\text {calcd }}=1.501 \mathrm{Mg} \mathrm{m}^{-3}, F(000)=864, \mu=4.09 \mathrm{~mm}^{-1}$, $T=123 \mathrm{~K}, 10,503$ measured reflections $\left(2 \theta_{\max }=144.4^{\circ}\right)$,
3660 independent $\left[R_{\mathrm{int}}=0.026\right.$ ], 241 parameters, $R_{l}$ [for $3633 I>2 \sigma(I)]=0.024, w R^{2}$ (for all data) $=0.066, S=1.10$, largest diff. peak and hole $=0.50 \mathrm{e} \AA^{-3} /-0.27 \mathrm{e} \AA^{-3}$.

CCDC 1,963,830 (3a), 1,963,831 (3d), and 1,963,832 (8a) contain the supplementary crystallographic data for this paper. These data can be obtained free of charge from The Cambridge Crystallographic Data Centre via www.ccdc. cam.ac.uk/data_request/cif.

Open Access This article is licensed under a Creative Commons Attribution 4.0 International License, which permits use, sharing, adaptation, distribution and reproduction in any medium or format, as long as you give appropriate credit to the original author(s) and the source, provide a link to the Creative Commons licence, and indicate if changes were made. The images or other third party material in this article are included in the article's Creative Commons licence, unless indicated otherwise in a credit line to the material. If material is not included in the article's Creative Commons licence and your intended use is not permitted by statutory regulation or exceeds the permitted use, you will need to obtain permission directly from the copyright holder. To view a copy of this licence, visit http://creativecommons.org/licenses/by/4.0/.

\section{References}

1. Pola S (2016) Significance of thiazole-based heterocycles for bioactive systems. Scope of selective heterocycles from organic and pharmaceutical perspective. Intech Open, Chapter 1, p 1

2. Yadlapalli RK, Chourasia OP, Jogi MP, Podile AR, Perali RS (2013) Med Chem Res 2:2975

3. Borisenko VE, Koll A, Kolmakov EE, Rjasnyi AG (2006) J Mol Struct 1163:101

4. Bhargava PN, Lakhan R, Tripathi K (1982) J Ind Chem Soc 59:773

5. Maulard T, Lagorce JF, Thomes JC, Raby C (1993) J Pharm Pharmacol 45:731

6. Maj J, Rogóz Z, Skuza G, Kolodziejczyk K (1997) J Neural Transm 104:525

7. Milne GWA (2000) Ashgate handbook of autineoplastic agents. Taylor \& Francis, London

8. De Souza MVN, De Almeida MV (2003) Quim Nova 26:366

9. Markus B, von Salome G, Christoph B, Werner JP (2004) Curr Drug Tar 24:1

10. Knadler MP, Bergstrom RF, Callaghan JT, Rubin A (1986) Drug Metab Dispos 14:175

11. Lednicer D, Mitscher LA, George GI (1990) Organic chemistry of drug synthesis, vol 4. Wiley, New York, p 95

12. Zia-ur-Rehman M, Choudary JA, Ahmad S (2005) Bull Korean Chem Soc 26:1771

13. Beuchet P, Varache-Lembege M, Neveu A, Leger JM, Vercauteren J, Larrouture S, Deffieux G, Nuhrich A (1999) Eur J Med Chem $34: 773$

14. Hamzé A, Rubi E, Arnal P, Boisbrun M, Carcel C, Salom-Roig X, Maynadier M, Wein S, Vial H, Calas M (2005) J Med Chem 48:3639

15. Chumakov VA, Demchenko AM, Krasovskii AN, Bukhtiarova TA, Melnichenko OA, Trinus FP, Lozinskii MO (1999) Pharm Chem J 33:421 (Translated from (1999) Khim-Farm Zh 33:20)

16. Vraneš M, Petrovic' L, Gadžurić S, Četojević-Simin D, Ranitović A, Cvetković D, Papović S, Tot A, Panić J, Milinković J (2019) J Chem Thermodyn 131:599 
17. Khan I, Ibrar A, Waqas M, White JM (2013) Phys Rev Res Int $3: 10$

18. Hassan AA, Mohamed SK, Mohamed NK, El-Shaieb KMA, Abdel-Aziz AT, Mague JT, Akkurt M (2016) J Sulfur Chem $37: 162$

19. Castells J, Domingo L, López-Calahorra F, Martí J (1993) Tetrahedron Lett 37:517

20. Reddy PL, Kumar KP, Satyanarayana S, Narender R, Reddy BVS (2012) Tetrahedron Lett 53:1546

21. Mohanazadeh F, Aghvami M (2007) Phosphorus. Sulfur Silicon Relat Elem 182:2467

22. Wang, Q, Zang H, Yang F, Cheng B, Ren Y, Xu X (2011) Adv Mater Res 332

23. Hassan AA, Mohamed NK, Aly AA, Tawfeek HN, Bräse S, Nieger M (2019) J Mol Struct 1176:346

24. Lee BW, Lee SD (2000) Tetrahedron Lett 41:3883

25. Hassan AA, Mohamed NK, El-Shaieb KMA Tawfeek HN, Bräse S, Nieger M (2016) Arkivoc vi:163
26. Zaharia V, Ignat A, Palibroda N, Ngameni B, Kuete V, Fokunang CN, Moungang ML, Ngadjui BT (2010) Eur J Med Chem 45:5080

27. Hassan AA, Mohamed NK, Aly AA, Tawfeek HN, Hopf H, Bräse S, Nieger M (2019) Mol Divers 23:821

28. El-Metwally NM, El-Shazly RM, Gabr IM, El-Asmy AA (2005) Spectrochim Acta 61A:1113

29. Nobuta T, Hirashima S-I, Tada N, Miura T, Itoh A (2010) Synlett 15:2335

30. Salama TA, Novak Z (2011) Tetrahedron Lett 52:4026

31. Sheldrick GM (2015) Acta Crystallogr A 71:3

32. Sheldrick GM (2015) Acta Crystallogr C 71:3

Publisher's Note Springer Nature remains neutral with regard to jurisdictional claims in published maps and institutional affiliations. 